\title{
Performance, milk fatty acid composition and behaviour of high- yielding Holstein dairy cows given a limited grazing period
}

by Atkins, N.E., Cianchi, C., Rutter, S.M., Williams, S.J., Gauld, C., Charlton, G.L. and Sinclair, L.A.

Copyright, publisher and additional information: this is the author accepted manuscript. The final published version (version of record) is available online via Wiley. This article may be used for non-commercial purposes in accordance with Wiley Terms and Conditions for Self-Archiving.

Please refer to any applicable terms of use of the publisher.

DOI: https://doi.org/10.1111/gfs.12471

Atkins, N.E., Cianchi, C., Rutter, S.M., Williams, S.J., Gauld, C., Charlton, G.L. and Sinclair, L.A.

Performance, milk fatty acid composition and behaviour of high-yielding Holstein dairy cows given a limited grazing period. Grass and Forage Science. 
1 Performance, milk fatty acid composition and behaviour of high-yielding

2 Holstein dairy cows given a limited grazing period

3

4 Running title: Grazing high-yielding cows

5

6 N. E. Atkins, C. Cianchi, S. M. Rutter, S. J. Williams, C. Gauld, G. L. Charlton and L. A.

$7 \quad$ Sinclair $^{1}$

8 Department of Animal Production, Welfare, and Veterinary Sciences, Harper Adams University,

9 Newport, Shropshire, TF10 8NB, United Kingdom

10

$11{ }^{1}$ Correspondence: Liam A. Sinclair, Department of Animal Production, Welfare, and Veterinary

12 Sciences, Harper Adams University, Newport, Shropshire, TF10 8NB, United Kingdom.

13 E-mail: 1sinclair@harper-adams.ac.uk

14 


\section{ACKNOWLEDGEMENTS}

16 The authors gratefully acknowledge the assistance of the Harper Adams University farm staff,

17 laboratory technicians and students. We are also grateful for the assistance of Dr Bob Mayes, James

18 Hutton Institute, for the n-alkane analysis. The financial support from AHDB Dairy is gratefully

19 acknowledged.

20

21 CONFLICT OF INTEREST STATEMENT

22 The authors declare that there are no conflicts of interest regarding the publication of this article.

24 ORCID

25 Norton E. Atkins http://orcid.org/0000-0002-7414-6956

26 Liam A. Sinclair http://orcid.org/0000-0002-8543-0063 


\section{Abstract}

28 The effects of a limited grazing period on the performance, behaviour and milk composition of high-

29 yielding dairy cows was examined. A total of 56 Holstein cows yielding $44.7 \pm 0.42 \mathrm{~kg} / \mathrm{d}$ were

30 allocated to one of four treatments in one of two, 4-week periods. Treatments were: Control (C) -

31 cows housed and offered TMR ad libitum; Early Grazing (EG) - cows grazed for $6 \mathrm{hr}$ after morning

32 milking then housed; Delayed Grazing (DG) - cows returned to housing for $1 \mathrm{hr}$ after morning milking

33 followed by grazing for $6 \mathrm{hr}$, then housed; Restricted TMR (RT) - cows grazed for $6 \mathrm{hr}$ after morning

34 milking then housed and fed TMR at $75 \%$ of ad libitum. Intake of TMR was highest in cows receiving

$35 \mathrm{C}$, intermediate in EG and DG, and lowest in RT at 26.9, 23.6, 24.7 and 20.3 $\mathrm{kg} \mathrm{DM} / \mathrm{d}$ respectively.

36 Pasture intake was similar in cows receiving EG or DG, but was higher in RT at 2.4, 2.0 and $3.5 \mathrm{~kg}$

$37 \mathrm{DM} / \mathrm{d}$ respectively. Milk yield was similar between cows receiving C, EG or DG, but lowest in RT at

$3845.7,44.2,44.9$ and $41.7 \mathrm{~kg} /$ cow respectively, whilst milk fat content of C18:3 n-3 was increased by

39 grazing. Cows in $\mathrm{C}$ spent more than $55 \mathrm{~min} / \mathrm{d}$ longer lying and had three additional lying bouts/d,

40 whilst lying bouts were shorter than for cows receiving EG, RT or DG. It is concluded that high-

41 yielding cows can be grazed for $6 \mathrm{hr} / \mathrm{d}$ with little impact on performance, provided TMR is available

42 ad-libitum when housed.

43

44 Keywords: behaviour, fatty acid, grazing, intake, milk production 


\section{1 | INTRODUCTION}

48 Grazing lactating dairy cows in many Western countries is decreasing as milk production per cow

49 increases, resulting in the greater use of summer housing and total mixed ration (TMR) feeding

50 (March et al., 2014; Wolf et al., 2015). Increasing the proportion of grazed pasture in the diet of dairy

51 cattle can however, offer economic, environmental, milk quality and animal welfare benefits

52 (Hennessy et al., 2015). For example, grazing dairy cows for part of the day can lower farm expenses

53 and increase profit in scenarios with high feed costs and low milk prices (Tozer et al., 2003), and

54 reduce the methane output of animals (Dall-Orsoletta et al., 2016; Mufungwe et al., 2014). Grazing

55 may also increase the concentration of fatty acids (FA) in milk that are beneficial to human health

56 (Barca et al., 2018; Mufungwe et al., 2014) and, because cows can exhibit motivation to be outside

57 at pasture (Motupalli et al., 2014), pasture access allows natural behaviour to be expressed which may

58 potentially improve animal welfare. Some farmers in European countries such as the United Kingdom

59 (UK), the Netherlands and Germany are currently incentivised by milk companies to graze milking

60 cows for a minimum of $6 \mathrm{hr}$ per day, while in Scandinavia, legislation requires cows to have outdoor

61 access for at least $6 \mathrm{hr}$ per day during the summer months. Providing pasture on its own however, is

62 insufficient to meet the nutrient requirements of high yielding dairy cows, limiting their daily milk

63 production to below $30 \mathrm{~kg} / \mathrm{cow}$ (Kolver \& Muller, 1998). Alternating grazing with TMR feeding

64 between the am and pm milking intervals has also been reported to lower milk yield compared with

65 housed and TMR fed cows (Bargo et al., 2002; Soriano et al., 2001), unless TMR was provided in the

66 field (Mufungwe et al., 2014). Recently it has been reported that limiting the time cows have at pasture

67 to $6 \mathrm{hr}$ per day allows cows in mid to late lactation to graze pasture and consume sufficient TMR to

68 maintain milk yield in comparison with housed and TMR fed cows (Dall-Orsoletta et al., 2016).

69 Despite the potential benefits from grazing, little is known about the effects of the length or

70 timing of a grazing period on the performance and behaviour of high yielding cows. Behavioural

71 studies have revealed that cows with free access to pasture and housing, rapidly consume a meal of

72 TMR following milking before going out to pasture (Charlton et al., 2011; Motupalli et al., 2014), a 
strategy that was able to maintain milk yield but limited pasture intake to less than $2 \mathrm{~kg} \mathrm{DM} / \mathrm{cow}$ per d. The diurnal response of cows to consume feed around dawn/morning milking (Gregorini, 2011) may also be used to increase the pasture intake of high yielding cows receiving limited access to pasture and fed a TMR when housed. Additionally, restricting the access of cows to TMR prior to grazing, or restricting the allowance of TMR when housed may promote grazing and pasture intake, although few studies have been conducted in this area. The primary objective of this study was to determine the effects of giving high yielding cows a $6 \mathrm{hr}$ grazing period compared with continuously housed cows on feed intake, milk yield, milk composition, and behaviour, and to determine the effects of delaying the $6 \mathrm{hr}$ grazing period or restricting TMR allowance with a $6 \mathrm{hr}$ grazing period. It was hypothesised that total feed intake and milk yield would be unaffected by a $6 \mathrm{hr}$ grazing period, but grazing behaviour, grass intake and milk composition would alter.

\section{2 | MATERIALS AND METHODS}

The study was conducted at Harper Adams University, Newport, Shropshire, UK $\left(52^{\circ} 780^{\prime} \mathrm{N}\right.$, $\left.2^{\circ} 434^{\prime} \mathrm{W}\right)$. Experimental work took place from the $12^{\text {th }}$ May to $14^{\text {th }}$ July 2015 , with all procedures involving animals, conducted in accordance with the UK Animals (Scientific Procedures) Act 1986 (amended 2013).

\subsection{Experimental design and routine}

\subsubsection{Animals and treatments}

Fifty-six dairy cows with previous experience of grazing that were (mean \pm SE) $89 \pm 5.3$ days postpartum, yielding $44.7 \pm 0.42 \mathrm{~kg}$ milk/d, with a live weight (LW) of $644 \pm 7.7 \mathrm{~kg}$ and a body condition score (BCS scale 1-5; Ferguson et al., 1994) of $2.78 \pm 0.029$ were used. Twenty-eight cows were allocated to one of four groups of seven cows for a period of $28 \mathrm{~d}$ duration. Another 28 cows were allocated in the same way, in a consecutive period of $28 \mathrm{~d}$. Period 1 occurred during May and June, and period 2 during June and July 2015. At the start of each period, the cows were stratified according 
99

100

101

to their milk yield, LW, feed intake and milk fat content measured in the week prior to allocation, and randomly allocated to one of four treatments. The treatments were; Control (C) - cows were continuously housed and offered a TMR ad libitum; Early grazing (EG) - cows grazed for 6 hr directly post am milking and then housed and offered TMR ad libitum; Delayed Grazing (DG) - cows were returned to housing for $1 \mathrm{hr}$ post am milking before being grazed for $6 \mathrm{hr}$ and then housed and offered TMR ad libitum; Restricted TMR (RT) - cows were grazed for $6 \mathrm{hr}$ directly post morning milking then housed and offered TMR that was restricted to $75 \%$ of ad libitum intake. Cows remained on treatment for four weeks with measurements undertaken during the final week.

Cows were milked twice daily at approximately 06:30 and 16:30 h. Immediately following morning milking, treatments $\mathrm{C}$ and DG were allowed to return to the free-stall housing and feeding area, while treatments EG and RT were separated as they left the milking parlour and moved to the pasture. After $1 \mathrm{hr}$, cows receiving treatment DG were separated and moved to the pasture. After $6 \mathrm{hr}$ at pasture, cows were gathered and returned inside (approximately 12:30 and 13:30 h for treatments EG/RT, and DG respectively). All cows had continuous access to water when indoors and at pasture.

\section{2 | Grazing and pasture allocation}

The grazing area consisted of a 3 ha paddock composed predominately of perennial ryegrass (Lolilum perenne), sown in spring 2011. The paddock had received $50 \mathrm{~kg} / \mathrm{ha} \mathrm{N}$ and $20 \mathrm{~kg} / \mathrm{ha} \mathrm{S}$ fertiliser, and was grazed once that grazing season with dairy cows before the beginning of the study. The area was subdivided with temporary electric fences to allow flexible rotational grazing. Cows were given a fresh strip of grass each day in blocks of three days, and then that block was back fenced and allowed to regrow. Each daily grass strip was further split into three parts of equal area and randomly allocated to the treatment groups who grazed independently. Grazing was counter balanced so that no group grazed the same area twice over a three-day block. Allocation of the grazing area was determined from herbage mass (HM), estimated daily prior to grazing by walking the paddock in a ' $\mathrm{W}$ ' pattern and taking 30 random measurements using a rising plate meter (Jenquip, Fielding, New Zealand). 
125 Daily fresh pasture allowance was initially set at $12 \mathrm{~kg} \mathrm{DM} / \mathrm{d}$ above a $4 \mathrm{~cm}$ base, but during the first

$12610 \mathrm{~d}$ of the study it became apparent that cows were consuming considerably less, and the daily

127 amount was reduced to $6 \mathrm{~kg} \mathrm{DM} /$ cow/d above a $4 \mathrm{~cm}$ base $(8 \mathrm{~kg} \mathrm{DM}$ on day one and $5 \mathrm{~kg} \mathrm{DM}$ in

128 each subsequent day of a $3 \mathrm{~d}$ block), plus the residual herbage from the previous days grazing during

129 days two and three of each block. Post-grazing herbage mass was also recorded daily for each group

130 using a rising plate meter. Target pre-grazing herbage mass was $2700-3000 \mathrm{~kg} \mathrm{DM} / \mathrm{ha}$ above ground

131 level, with a mean of $2842 \pm 89.2 \mathrm{~kg} \mathrm{DM} /$ ha during the collection period. A group of non-lactating

132 cows were used to graze residual herbage to $1500-1600 \mathrm{~kg} \mathrm{DM} / \mathrm{ha}$ above ground level, and

133 mechanical topping was used to maintain pasture quality when necessary.

$135 \quad 2.3$ | Housing and TMR feeding

136 When housed, the cows were located together in the same portion of a free-stall building containing 137 Super Comfort cubicles fitted with foam mattresses (IAE, Stoke-on-Trent, United Kingdom). Fresh 138 TMR was delivered at approximately 08:00 h daily using a forage mixer wagon (Hi-spec Engineering 139 Ltd, Bagenalstown, Ireland) calibrated to $\pm 0.1 \mathrm{~kg}$, and was composed of maize silage, lucerne silage 140 and straight feeds, formulated according to Thomas (2004; Table 1). The TMR was accessed via 30 141 electronic roughage intake control (RIC) bins (Insentec, Marknesse, The Netherlands). Cows were 142 trained to use the bins at least one week prior to each study period. Cows receiving treatments C, EG 143 or DG received ad-libitum access to the TMR, with those receiving RT were restricted to $75 \%$ of the 144 DM intake of their corresponding pair in treatment $\mathrm{C}$.

\section{4 | Experimental measurements}

\section{$147 \quad$ 2.4.1 | Feed intake milk yield, composition and live weight}

148 Grass and TMR samples were collected during the final five days of each period. Samples of the 149 TMR were collected within 10 min of feeding, and grass 'pluck' samples were taken at approximately $150 \quad 07: 30$ and 11:30 $\mathrm{h}$ as described by Smit et al. (2005) to represent the herbage in the grazed horizon, 
and stored at $-20^{\circ} \mathrm{C}$ prior to subsequent analysis. Individual grass intake was estimated using the n-

152 alkane method as described by Mayes et al. (1986). For the final $12 \mathrm{~d}$ of each period, a daily dose of 153 C32 alkane (dotriacontane) was thoroughly incorporated into the TMR at $2.0 \mathrm{~g} / \mathrm{cow} / \mathrm{d}$. Briefly; alkane powder (56 g) was mixed with $1 \mathrm{~kg}$ of the straight feeds mix, and the straight feeds plus alkane mix was then scattered across the TMR and mixed for 10 minutes. The daily TMR intake was then used to calculate the quantity of n-alkane consumed by each cow. Faecal samples for each cow were collected during the final $5 \mathrm{~d}$ of each period between 04:00 - 06:00 and 16:00 - 18:00 $\mathrm{h}$ from naturally voided faecal deposits of certain origin at the time of deposition, and frozen at $-20^{\circ} \mathrm{C}$. Milk yield was recorded at each milking for all cows during the collection period, with sub-samples collected on four separate occasions $(2 \mathrm{x}$ am and $2 \mathrm{x} \mathrm{pm})$ during week 4 of each period for subsequent analysis. Cow LW was measured (Trutest, Auckland, New Zealand) and BCS (Ferguson et al., 1994) recorded at the start and end of each four-week treatment period at approximately 16:30 h.

\subsection{2 | Visual and automatic behaviour recording}

165 On days 4 and 7 of week 3 of each experimental period, visually observed behaviour was recorded for cows receiving treatments EG, DG and RT for the $6 \mathrm{hr}$ whilst they were at pasture. Every $5 \mathrm{~min}$ during each observational period the posture (lying, standing, walking) and jaw activity (grazing, ruminating, drinking, idling) of each cow was recorded. Binoculars were used when necessary for accurate identification of each cow and to maintain a distance from the cows to prevent disturbance. Prior to the study each cow had an accelerometer (IceQube, IceRobotics Ltd, Edinburgh, UK) attached to their hind left leg. The sensors recorded lying time (LT $\mathrm{min} / \mathrm{d}$ ), frequency of lying bouts (LB/d), average lying bout duration (LBD; min/bout) and step count (steps/d). All data were stored

173 within the accelerometer device and subsequently uploaded each time the cows walked past a reader

174 (CowAlert system, IceRobotics Ltd, Edinburgh, UK), at the entrance to the milking parlour. Time 175 spent eating TMR was determined using the data recorded by the RIC feeders for each cow during 176 the final week of each period. 


\subsection{Chemical analysis}

179 Grass and TMR samples were bulked by period, and a sub-sample of grass was freeze dried (Edwards 180 Modulyo, Bolton, UK) and TMR oven dried to constant weight and analysed (AOAC, 2012) for ash 181 (942.05) and crude protein (CP; 990.03) content. Faecal samples were bulked within cow and a subsample freeze dried for subsequent analysis. Fibre content of the TMR and grass was assessed according to the method of Van Soest et al. (1991), and water soluble carbohydrate (WSC) according to Thomas (1977). Grass metabolisable energy content (ME; MJ/kg DM) was predicted from the concentration of modified acid detergent fibre (MADF; Givens et al., 1990). Milk samples were analysed for fat, protein and lactose content using a Milkoscan Minor (FOSS, Warrington, UK) calibrated according to AOAC (2012), and energy corrected milk yield (ECM) calculated using milk yield, milk fat, protein and lactose content (Sjaunja et al., 1990). Fatty acid methyl esters (FAME) in hexane were prepared from milk fat by the method of Feng et al., (2010) and from feeds by the method of Jenkins (2010). Individual FAME were determined by GLC (Hewlett Packard 6890, Wokingham, UK) fitted with a CP-Sil 88 column (100 m x $0.25 \mathrm{~mm}$ i.d. x $0.2 \mu \mathrm{m}$ film). Hydrogen was used as the carrier gas and a programmed temperature sequence was used; further details and conditions have been described previously (Lock et al., 2006). Grass, TMR and faecal samples were analysed for nalkanes and grass intake for each cow calculated from the concentrations of the naturally occurring odd-chain (C33) and the dosed even-chain (C32) n-alkane using the method described by Mayes et al. (1986). Alkane analysis was conducted on a GLC (Phillips PU 4500; Phillips, Surrey, UK), fitted with a $30 \mathrm{~m}$ x $0.32 \mathrm{~mm} 0.25 \mu \mathrm{m}$ fused silica capillary column (Restec Corporation, Bellefonte, USA) using helium as the carrier gas. Oven temperature was programmed at $190^{\circ} \mathrm{C}$ for 3 min and then increased by $6^{\circ} \mathrm{C}$ per min until $316^{\circ} \mathrm{C}$.

\subsection{Statistical analysis}

Data were evaluated by ANOVA in Genstat v.17 (VSN International 2015). Feed intake, milk 
production, fatty acid, LW and BCS variables were tested for normality and fitted to the model:

$$
\mathrm{y}_{\mathrm{ijk}}=\mu+P_{\mathrm{i}}+B_{\mathrm{j}}+\mathrm{T}_{k}+\epsilon_{\mathrm{ijk}}
$$

where $\mathrm{y}_{\mathrm{ijk}}=$ dependent variable; $\mu=$ overall mean; $\mathrm{P}_{\mathrm{i}}=$ random effect of period; $\mathrm{B}_{\mathrm{j}}=$ random effect of block; $\mathrm{T}_{\mathrm{k}}=$ effect of treatment; $\varepsilon_{\mathrm{ijkw}}=$ residual error. Measurements of feed intake, milk production,

LW and BCS taken prior to allocation were used as covariates in the model if appropriate. Behaviour data were evaluated using the same model for the individual animals. Differences were considered significant at $p<0.05$ and a least significant difference test was conducted post hoc.

\section{3 | RESULTS}

\section{1 | Chemical analysis of the diets}

213 The DM content of the TMR was more than double that of the grazed grass (Table 1), but the ME and

$214 \mathrm{CP}$ content was similar in both feeds, with a mean value of $12.2 \mathrm{MJ} / \mathrm{kg} \mathrm{DM}$ and $176 \mathrm{~g} / \mathrm{kg} \mathrm{DM}$

215 respectively. The WSC and NDF concentration was 121 and $61 \mathrm{~g} / \mathrm{kg}$ DM higher in the grazed grass 216 than the TMR respectively. Total FA content was $8 \mathrm{~g} / \mathrm{kg}$ DM higher in the TMR than the grass. The major FA in grass was C18:3 n-3, which contributed 41g/100g FA, whereas in the TMR C16:0, C18:1n-9 and C18:2n-6 were the major FA, each contributing approximately $28 \mathrm{~g} / 100 \mathrm{~g}$ FA.

\subsection{Intake and performance}

221 Intake of TMR was highest $(p<0.05)$ in cows offered $\mathrm{C}$, and was approximately $3 \mathrm{~kg} \mathrm{DM} / \mathrm{d}$ higher

222 than in cows offered EG or DG, which did not differ $(p>0.05$; Table 2$)$. The lowest intake of TMR was in cows receiving RT, which was $75 \%$ of the value of cows receiving the Control. In contrast, grass intake was highest $(p<0.05)$ in cows receiving RT at $3.5 \mathrm{~kg} \mathrm{DM} / \mathrm{d}$ compared to the mean value of $2.2 \mathrm{~kg}$ DM in those receiving EG or DG. In the $6 \mathrm{hr}$ prior to grazing, cows receiving DG had the highest $(p<0.05)$ TMR intake, at $7.6 \mathrm{~kg}$ DM, whilst those in $\mathrm{C}$, EG and RT were similar at $4.5 \mathrm{~kg}$ DM (Figure 1). In the $6 \mathrm{hr}$ following grazing, cows receiving EG, DG and RT had a similar $(p>0.05)$ 
0.05 ) at $7.4 \mathrm{~kg}$ DM. Total DM intake was similar in cows receiving C, EG or DG (mean value of 26.5

$230 \mathrm{~kg} / \mathrm{d}$ ), and was approximately $2.7 \mathrm{~kg} \mathrm{DM} / \mathrm{d}$ higher than cows receiving RT ( $p<0.05$; Table 2). Milk

231 yield was similar in cows receiving C, EG or DG, with a mean value of $44.9 \mathrm{~kg} / \mathrm{d}$, but was lower $(p$

$232<0.05)$ in cows fed RT compared to C or DG. However, ECM was similar $(p>0.05)$ between

233 treatments, with a mean value of $37.6 \mathrm{~kg} / \mathrm{d}$. There was no effect $(p>0.05)$ of treatment on milk fat or

234 protein content, whereas milk protein and lactose yield were higher $(p<0.05)$ in cows receiving $\mathrm{C}$

235 compared to RT. Cows receiving C also had a higher LW and greater LW gain than those receiving

236 RT $(p<0.05)$, with EG and DG being intermediate. There was no effect $(p>0.05)$ of treatment on

237 BCS or BCS change.

$239 \quad 3.3 \mid$ Milk fatty acid profile

240 Milk fat content of C10:0 and C14:0 were lowest $(p<0.05)$ in cows receiving RT and highest in EG

241 (Table 3). The odd-chain FA C15:0 was lowest in milk from cows fed RT and highest in C $(p<0.05)$,

242 whereas C17:0 was lowest in cows receiving C and highest in those offered DG $(p<0.05)$. There was

243 no effect $(p>0.05)$ of treatment on the trans FA content of milk, except C18:1 t12, which was lower

244 in $\mathrm{C}$ than any of the treatments that received access to pasture. Milk content of C18:1 c9 was highest

$245(p<0.05)$ in cows offered RT and lowest in cows offered EG. There was an effect of the inclusion of

246 access to pasture on the milk fat content of C18:3 n-3, which was approximately one-third higher in

247 cows receiving any of the grazing treatments (EG, DG or RT) compared to those receiving C ( $p<$

248 0.001). Cows receiving RT had a lower content of saturated and a higher content of MUFA compared

249 to those offered EG $(p<0.05)$. Similarly, milk FA of $<$ C16 was lowest $(p<0.05)$ in cows receiving

250 RT compared to EG, whereas milk FA $>$ C16 was highest $(p<0.05)$ in cows receiving RT compared 251 to $\mathrm{C}$.

\subsection{Behavioural measurements}

254 When visually observed, cows that had access to pasture spent on average $42.9 \%$ of their time at 
pasture grazing, $32.7 \%$ ruminating, $1.4 \%$ drinking and $22.9 \%$ idle, which was not affected by

256

257

258

259

260

261

treatment $(p>0.05$; Table 4). There was also no difference $(p>0.05)$ in jaw activity (grazing, ruminating, drinking and idling) between cows receiving EG, DG or RT. Whilst at pasture, cows spent on average $42.2 \%$ of their time lying, and $55.7 \%$ standing, which was not affected by treatment $(p>$ $0.05)$. In contrast, there was a difference $(p<0.01)$ in the proportion of time spent walking at pasture; cows receiving EG spent a greater proportion of their time walking than either DG or RT, which did not differ.

\section{When activity was recorded over $24 \mathrm{~h} / \mathrm{d}$ (during pasture access and indoors) using} accelerometers, there was a difference $(p<0.001)$ between cows receiving $\mathrm{C}$ compared to those receiving EG, RT or DG in all behavioural activities. Cows receiving $\mathrm{C}$ spent at least $55 \mathrm{~min} / \mathrm{d}$ longer lying and had three additional LB/d, whilst lying bouts were shorter than for cows receiving EG, RT or DG ( $p<0.001$; Table 4$)$. Cows in C also took less steps/d compared to EG, RT or DG ( $p$ $<0.001)$. There were no differences $(p>0.05)$ in behavioural activity, measured using the accelerometers, between cows receiving treatments EG, RT or DG. When recorded by the RIC system, time spent feeding on TMR was highest $(p<0.05)$ in C $(191 \pm 11.1 \mathrm{mins} / \mathrm{d})$, lowest in RT $(124 \pm 10.8 \mathrm{mins} / \mathrm{d})$ and intermediate in EG and RT (both $152 \pm 10.8 \mathrm{mins} / \mathrm{d})$.

\section{4 | Discussion}

\subsection{Intake and performance}

The current study was conducted over the summer months when the reproductive growth of pasture can reduce its feed quality compared to earlier in the grazing season (Givens et al., 1993). Summer grazing is, however, common practice on many dairy systems, with approximately $92 \%$ of dairy farms in Britain grazing for at least part of the day during summer (March et al., 2014). Typical values for pasture ME on commercial farms in the UK are less than $12 \mathrm{MJ} \mathrm{ME} / \mathrm{kg} \mathrm{DM}$ over the summer (Wilkinson et al., 2014). In comparison, the grass used in the current study, at 12.5 and $12.0 \mathrm{MJ}$ $\mathrm{ME} / \mathrm{kg} \mathrm{DM}$ in the first and second periods respectively, was above average, and similar to the TMR. 
281 Similarly, NDF and ADF content of the pasture was low (Wilkinson et al., 2014), indicative of a leafy

282 well-managed pasture (Dale et al., 2018), although the pasture contained a moderate concentration of

283 CP, but CP was similar to the TMR and sufficient for animal performance (Sinclair et al., 2014). The

284 cows in the current study grazed laxly, with post-grazing HM of approximately $2400 \mathrm{~kg} \mathrm{DM} / \mathrm{ha}$ above

285 ground level, and the high-quality pasture was maintained using hard grazing with dry cows following

286 the experimental cows, then mechanical topping if still required for an even sward. Commercially,

287 following grazing with dry cows may be insufficient to maintain pasture quality, as dry cows may be

288 too few in number on a commercial farm to keep up with a grazing rotation and greater use of

289 mechanical topping may be required with an associated increase in pasture wastage.

290 The major limiting factor for production in pasture-based systems for dairy cows is often not

291 grass quality, but DM intake (Kolver, 2003). The current study aimed to maintain overall DM intake,

292 with TMR offered ad libitum while housed, except for cows in RT that were restricted to $75 \%$ of $a d-$

293 libitum intake, and the provision of sufficient grass HM to facilitate a high rate of intake while at

294 pasture. A feeding bout was expected immediately following morning milking, therefore moving the

295 cows receiving EG to pasture at this point was hypothesised to promote a greater desire to consume

296 grass, and therefore increase grass intake. Delaying access to pasture for cows in DG following

297 milking was hypothesised to reduce grass intake as a result of increased TMR intake prior to grazing.

298 The DMI results for the 6-hr period prior to grazing indicate that cows in DG did consume the greatest

299 quantity of TMR during this period, however, grass intake of cows in EG or DG was similar (mean

300 of $2.2 \mathrm{~kg} \mathrm{DM} / \mathrm{cow} / \mathrm{d}$, or $8.2 \%$ of total DMI). Approximately $40 \%$ of the time at pasture for cows in

301 EG or DG was spent grazing, and therefore the rate of intake at pasture was low in comparison with

302 predominately pasture-fed dairy cows. For example, in cows with unrestricted access to pasture the

303 mean rate of intake of grass ranged from 16.2 to $44.8 \mathrm{~g}$ of DM/min (Pérez-Prieto \& Delagarde, 2013),

304 and at these values, the $6 \mathrm{~kg} \mathrm{DM} / \mathrm{d}$ offered in the current study could have been consumed between

3052.2 and $6.2 \mathrm{hr}$ at pasture. Low intakes of grass in TMR-fed dairy cows offered pasture has also been

306 reported in previous work, with Motupalli et al. (2014) reporting a grass intake of only 0.8 to $1.6 \mathrm{~kg}$ 
$307 \mathrm{DM} /$ cow/d when cows had free access to pasture and TMR. Similarly, in a study comparing

308 continuous housing with daytime or night time grazing, either with or without TMR access at pasture,

309 Mufungwe et al. (2014) reported grass intakes of $1.1 \mathrm{~kg} \mathrm{DM} / \mathrm{cow}$ during the day, or $0.7 \mathrm{~kg} \mathrm{DM} / \mathrm{cow}$

310 at night, when cows had access to TMR while at pasture. When TMR was not provided in the field,

311 Mufungwe et al. (2014) reported that grass intake increased to $2.6 \mathrm{~kg} \mathrm{DM} / \mathrm{cow}$, but total DMI was

312 decreased. The continuously housed cows in the current study were able to consume more feed ( 8.5

$313 \mathrm{~kg} \mathrm{DM}$ ), during the $6 \mathrm{hr}$ following the morning milking, which corresponds to the grazing period of

314 the other treatments. Despite this, cows in both EG and DG achieved a similar total DMI to C cows,

315 which was a consequence of the grazing groups increasing the duration and intensity of TMR feeding

316 at other times of the day.

317 It was hypothesised that the intake of grass would be highest in cows receiving RT, as these

318 animals would be hungrier and have a greater drive to consume grass, which would compensate for

319 the restriction of the TMR. Although the intake of grass for RT cows was higher than DG or EG, it

320 was still only $3.5 \mathrm{~kg} \mathrm{DM} / \mathrm{cow}$, approximately $14.7 \%$ of total DMI for these cows, and the time spent

321 grazing (47.7\% of time at pasture) was not different to cows in either of the other two grazing groups.

322 Previous research has reported a longer grazing time when TMR was more severely restricted. For

323 example, Fajardo et al. (2015), reported that when cows were offered $50 \%$ of the TMR of

324 continuously housed cows and had $6 \mathrm{hr} / \mathrm{d}$ of grazing, they spent $64 \%$ of their time at pasture grazing,

325 whilst cows with $9 \mathrm{hr} / \mathrm{d}$ of pasture access, grazed for $52 \%$ of the time, with a similar grazing duration

326 for both groups. In combination, these results suggest that when TMR is the major component of a

327 cows DM intake, their preference may be to wait for the TMR if it is not immediately available, even

328 if this results in a reduced total DMI. Alternatively, evidence suggests that grazing is a partially

329 learned behaviour (Charlton \& Rutter, 2017), and thus limited early grazing exposure or limited

330 incentive to graze may limit the intake of grass, although all the cows in the current study had

331 extensive access to pasture prior to the study.

332 Milk yield reflected the pattern of DM intake, with a similar yield in cows receiving C, EG or 
333 DG (mean of $44.9 \mathrm{~kg} / \mathrm{d}$ ), and was $3.2 \mathrm{~kg} / \mathrm{d}$ lower in cows receiving RT. In contrast, previous research

334 has reported that cows fed TMR alone had a higher milk yield than those receiving a combination of 335 grazing and TMR (Bargo et al., 2002; Mufungwe et al., 2014; Soriano et al., 2001). However, these 336 studies had a longer grazing period (7-12 hr/d), suggesting that the $6 \mathrm{hr} / \mathrm{d}$ used in the current study 337 was within the ability of cows yielding $45 \mathrm{~kg} / \mathrm{d}$ to compensate for a period without access to TMR. 338 Although DMI from grass was low, this small amount may have had a positive impact on the overall 339 nutrient digestibility of the diet, and it is also possible that there was increased mobilisation of adipose 340 tissue in cows that grazed grass which may have supported the high level of milk production, as LW 341 gain was lower in cows receving EG or RT compared to C. Chapinal et al. (2010) reported that early 342 lactation cows could be grazed for approximately 10.5 hr overnight from 20:00 h without a reduction 343 in TMR intake or milk production. However, both the TMR intake and milk yield were lower in the 344 study of Chapinal et al. (2010) at $15.5 \mathrm{~kg} \mathrm{DM} / \mathrm{d}$ and $38.3 \mathrm{~kg}$ milk/d, and the cows may therefore have 345 been able to consume sufficient TMR before overnight grazing with less reliance on the pasture. Other 346 studies have observed negative production responses in early lactation when pasture has been a major 347 component of the diet. For example, Fajardo et al. (2015), restricted the TMR of cows to 50\% with 348 either a 6 or $9 \mathrm{hr}$ of grazing per day for 13 weeks from calving, and reported a milk yield of $33.8 \mathrm{~kg} / \mathrm{d}$, 349 which was approximately $91 \%$ of the continuously housed cows. In the current study, with a $75 \%$ 350 TMR allowance, the cows receiving RT did not fully compensate for their reduced DM intake when 351 at pasture, despite sufficient time and HM allowance, with the consequence that their yield was 352 reduced.

353 No difference was observed in milk fat or protein concentration in the current study, although 354 milk fat content was nominally higher in RT and subsequently ECM was similar in all treatments. 355 Lower milk yield of cows receiving RT compared to C resulted in a lower daily yield of protein, but 356 not fat. Milk fat concentration has previously been reported to increase (Fajardo et al., 2015), decrease 357 (Dall-Orsoletta et al., 2016; Morales-Almaráz et al., 2010), or remain unaffected (Soriano et al., 2001; 358 Vibart et al., 2008) when grazing was included in the diet of TMR-fed cows. These differences may 
359 be a function of NDF intake, as pasture is typically higher in NDF than the TMR, which may be

360 expected to increase milk fat concentration (Sutton, 1986). In the current study, the NDF content of

361 the grass was approximately $20 \%$ higher than the TMR, but the intake of the grass was low and the

362 subsequent effects on total NDF intake small. Additionally, other factors of the TMR, such as particle

363 length and physically effective NDF content, may also have a large influence on milk fat content

364 (Tayyab et al., 2018, 2019).

\section{2. | Milk fatty acid profile}

Increasing forage intake has the potential to improve the FA profile of milk by increasing

unsaturated and decreasing saturated FA, with increases in beneficial long chain and reductions in medium chain fatty acids (Dewhurst et al., 2006; Elgersma, 2015). For example, pasture-fed vs. maize silage-based TMR-fed cows generally produce milk fat with increased concentrations of 18:3 n-3, $\mathrm{C} 18: 2 \mathrm{c} 9, \mathrm{t}-11, \mathrm{C} 18: 1 \mathrm{t} 11, \mathrm{C} 18: 1 \mathrm{n}-9$, and $\mathrm{C} 18: 0$, with decreasing concentrations of $\mathrm{C} 12: 0, \mathrm{C} 14: 0$ and C16:0 (Dewhurst et al., 2006). Other studies that have also incorporated a period of grazing with TMR feeding have also reported increases in the C18:3 n-3 concentration of milk fat (Barca et al., 2018; Morales-Almaráz et al., 2010; Vibart et al., 2008). In the current study, there was an increase of C18:3 n-3 by approximately $29 \%$ in the milk fat of cows with a 6 -hr grazing period compared to TMR-only cows, although the amount was still comparatively small at less than $0.5 \%$ of the total fat content. The major source of C18:3 n-3 was from the grass, which contained 41g/100g FA compared with only $2.8 \mathrm{~g} / 100 \mathrm{~g}$ FA in the TMR. Despite the low intake of grass of cows receiving EG, DG or RT, the intake of C18:3 n-3 was calculated to be increased by approximately 43, 36 and $64 \mathrm{~g} / \mathrm{cow} / \mathrm{d}$, respectively, compared to C. Approximately $90 \%$ of $\mathrm{C} 18: 3$ n-3 would be expected to be biohydrogenated in the rumen (Sinclair et al., 2005), but would still result in a net absorption of between 4 and $6 \mathrm{~g} / \mathrm{d}$, and may explain the increase of this FA in milk of the grass-fed cows. 
385 (Elgersma, 2015). An increase in these intermediaries may also have been expected with the inclusion

386 of grass in the diet, but no differences were observed in the milk from the cows receiving the $6 \mathrm{hr}$

387 grazing compared to continuously housed cows, although C18:1 t-12 was higher and C18:2 t-10,c12

388 tended to be higher in cows in grazing treatments compared to C. The FA C18:2 t-10,c12 is a potent

389 inhibitor of milk fat synthesis (Lock et al., 2006), and although not statistically significant, milk fat

390 content was numerically lowest in $\mathrm{C}$ and was relatively low overall, with a mean of $32.1 \mathrm{~g} / \mathrm{kg}$ across

391 all treatments. Factors other than the proportion of grass in the diet can also affect the concentration

392 of these FA in milk fatty acids, with for example basal forage and concentrate composition and ratio,

393 pasture composition and vegetative state, rumen $\mathrm{pH}$ and animal factors playing an important role

394 (Dewhurst et al., 2006).

395 Overall, none of the grazing treatments substantially affected total SAT, MUFA or PUFA content

396 of the milk compared with continuously housed cows, although restricting TMR allowance did result

397 in a lower SAT, higher MUFA, less de novo synthesised FA and more preformed FA in milk than

398 unrestricted, early-grazed cows. Some of the differences in the milk FA composition between grazing

399 treatments may be explained by the higher grass intake in RT compared to EG, and potentially less

400 selective grazing or grazing to a lower sward horizon altering the FA profile, as grazing intensity has

401 been shown to alter the chemical composition of grass (Dale et al., 2018).

\section{3. | Behaviour}

Lying is a high-priority activity for dairy cows, and is essential for health, welfare and productivity (Charlton \& Rutter, 2017). When soil conditions are dry, and temperature and humidity temperate, cows have been reported to show a preference for lying outside (Krohn et al., 1992; Legrand et al., 2009). The cows that received $6 \mathrm{hr} / \mathrm{d}$ of grazing in the current study spent approximately $42 \%$ of their time at pasture lying down, compared with $38 \%$ of their time indoors lying. Continuously housed cows spent just over one hr/d more lying than those grazing, although the 
411 is likely to be due to the additional time required for grazing. Previous studies have found that

412 continuously housed cows will spend an average of 3 to $6 \mathrm{hr} / \mathrm{d}$ feeding (Charlton \& Rutter, 2017).

413 Although cows in C had a high DMI, which they were able to achieve in a relatively short feeding

414 time of $191 \mathrm{~min}$, cows in EG and DG achieved a similar DMI but in 298 minutes of feeding plus

415 grazing. Interestingly, cows in RT spent a similar total time feeding and grazing (296 min), whilst

416 total lying time was also similar between the grazing groups (566 $\mathrm{min})$. There may therefore have

417 been a conflict between lying and feeding/grazing, with the grazed cows in the current study perhaps

418 reaching a minimum acceptable lying time, or maximum feeding time with the conditions presented

419 to them. Alternatively, social interactions may have moderated the grazing behaviour of cows

420 receiving RT, although each treatment grazed in an independent area. Variation in grazing behaviour

421 has been observed to be related to milk yield, which influences appetite (Rind and Phillips, 1999) and

422 the similarity in grazing time between groups may be due to the lower milk yield of RT cows rather

423 than social influence from the adjacent groups.

\section{$425 \quad 5$ | CONCLUSIONS}

426 For cows with a milk yield of approximately $45 \mathrm{~kg} / \mathrm{d}$, providing access to pasture for $6 \mathrm{hr}$ per day did 427 not have a major effect on intake or milk performance, with grass only contributing approximately $4288 \%$ of DMI. In contrast, having access to pasture for $6 \mathrm{hr} / \mathrm{d}$ and restricting TMR intake to $75 \%$ of $\mathrm{ad}$ 429 libitum resulted in the highest grass intake, but this was not sufficient to compensate for the lower 430 TMR intake, and milk performance was reduced. Providing access to pasture can increase the milk 431 content of C18:3 n-3 but values were still low, at under $0.5 \%$ of the total fat. Having access to pasture 432 also resulted in cows spending more time feeding and spending less time lying, but when they did lie, 433 they did so for a longer period of time. 
438 Barca, J., Carriquiry, M., Olazabal, L., Fajardo, M., Chilibroste, P., \& Meikle, A. (2018). Milk fatty 439 acid profile from cows fed with mixed rations and different access time to pastureland during 440 early lactation. Journal of Animal Physiology and Animal Nutrition, 102(3), 620-629.

Chapinal, N., Goldhawk, C., de Passillé, A. M., von Keyserlingk, M. A. G., Weary, D. M., \& Rushen, J. (2010). Overnight access to pasture does not reduce milk production or feed intake in dairy cattle. Livestock Science, 129(1-3), 104-110. https://doi.org/10.1016/J.LIVSCI.2010.01.011

Charlton, G. L, Rutter, S. M., East, M., \& Sinclair, L. A. (2011). Effects of providing total mixed rations indoors and on pasture on the behavior of lactating dairy cattle and their preference to be indoors or on pasture. Journal of Dairy Science, 94(8), 3875-3884.

$$
\text { https://doi.org/10.3168/jds.2011-4172 }
$$

Charlton, G. L., \& Rutter, S. M. (2017). The behaviour of housed dairy cattle with and without pasture access: A review. Applied Animal Behaviour Science, 192(April 2018), 2-9.

https://doi.org/10.1016/j.applanim.2017.05.015

Dale, A. J., Laidlaw, A. S., McGettrick, S., Gordon, A., \& Ferris, C. P. (2018). The effect of grazing intensity on the performance of high-yielding dairy cows. Grass and Forage Science, 73(3), 798-810. https://doi.org/10.1111/gfs.12350

Dall-Orsoletta, A. C., Almeida, J. G. R., Carvalho, P. C. F., Savian, J. V., \& Ribeiro-Filho, H. M. N. (2016). Ryegrass pasture combined with partial total mixed ration reduces enteric methane emissions and maintains the performance of dairy cows during mid to late lactation. Journal of 
Dewhurst, R. J., Shingfield, K. J., Lee, M. R. F., \& Scollan, N. D. (2006). Increasing the concentrations of beneficial polyunsaturated fatty acids in milk produced by dairy cows in high-forage systems. Animal Feed Science and Technology, 131(3-4), 168-206. https://doi.org/10.1016/J.ANIFEEDSCI.2006.04.016

Elgersma, A. (2015). Grazing increases the unsaturated fatty acid concentration of milk from grassfed cows: A review of the contributing factors, challenges and future perspectives. European Journal of Lipid Science and Technology, 117(9), 1345-1369.

Fajardo, M., Mattiauda, D. A., Motta, G., Genro, T. C., Meikle, A., Carriquiry, M., \& Chilibroste, P. (2015). Use of mixed rations with different access time to pastureland on productive responses of early lactation Holstein cows. Livestock Science, 181, 51-57. https://doi.org/10.1016/j.livsci.2015.09.023

Feng, S., Lock, A. L., \& Garnsworthy, P. C. (2010). Technical Note: A Rapid Lipid Separation Method for Determining Fatty Acid Composition of Milk. Journal of Dairy Science, 87(11), 3785-3788. https://doi.org/10.3168/jds.s0022-0302(04)73517-1

Ferguson, J. D., Galligan, D. T., \& Thomsen, N. (1994). Principal descriptors of body condition score in Holstein cows. Journal of Dairy Science, 77(9), 2695-2703. https://doi.org/10.3168/jds.S0022-0302(94)77212-X

Givens, D. I., Everington, J. M., \& Adamson, A. H. (1990). The nutritive value of spring-grown herbage produced on farms throughout England and wales over 4 years. III. The prediction of energy values from various laboratory measurements. Animal Feed Science and Technology, 27(3), 185-196. https://doi.org/10.1016/0377-8401(90)90081-I

Givens, D. I., Moss, A. R., \& Adamson, A. H. (1993). Influence of growth stage and season on the energy value of fresh herbage. 1. Changes in metabolizable energy content. Grass and Forage Science, 48(2), 166-174. https://doi.org/10.1111/j.1365-2494.1993.tb01849.x 
489 Gregorini, P. (2011). Diurnal grazing pattern: its physiological basis and strategic management.

490 Animal Production Science, 52(7), 416-430. https://doi.org/10.1071/AN11250

491 Hennessy, D., Delaby, L., Van den Pol-van Dasselaar, A., \& Shalloo, L. (2015). Possibilities and 492 constraints for grazing in high output dairy systems. Grassland Science in Europe, 20, 151$493 \quad 162$.

494 Jenkins, T. C. (2010). Technical note: Common analytical errors yielding inaccurate results during 495 analysis of fatty acids in feed and digesta samples. Journal of Dairy Science, 93(3), 1170496 1174. https://doi.org/10.3168/jds.2009-2509

497 Kolver, E. S., \& Muller, L. D. (1998). Performance and nutrient intake of high producing Holstein 498 cows consuming pasture or a total mixed ration. Journal of Dairy Science, 81(5), 1403-1411. 499 https://doi.org/10.3168/jds.S0022-0302(98)75704-2

500 Kolver, E. S. (2003). Nutritional limitations to increased production on pasture-based systems. $501 \quad$ Proceedings of the Nutrition Society, 62(02), 291-300. https://doi.org/10.1079/PNS2002200

502 Krohn, C. C., Munksgaard, L., \& Jonasen, B. (1992). Behaviour of dairy cows kept in extensive 503 (loose housing/pasture) or intensive (tie stall) environments I. Experimental procedure, 504 facilities, time budgets — diurnal and seasonal conditions. Applied Animal Behaviour Science, 505 34(1-2), 37-47. https://doi.org/10.1016/S0168-1591(05)80055-3

Legrand, A. L., von Keyserlingk, M. A. G., \& Weary, D. M. (2009). Preference and usage of pasture versus free-stall housing by lactating dairy cattle. Journal of Dairy Science, 92(8), 3651-3658. https://doi.org/10.3168/JDS.2008-1733

Lock, A. L., Teles, B. M., Perfield, J. W., Bauman, D. E., \& Sinclair, L. A. (2006). A Conjugated Linoleic Acid Supplement Containing trans-10, cis-12 Reduces Milk Fat Synthesis in Lactating Sheep. Journal of Dairy Science, 89(5), 1525-1532.

513 March, M. D., Haskell, M. J., Chagunda, M. G. G., Langford, F. M., \& Roberts, D. J. (2014). 514 Current trends in British dairy management regimens. Journal of Dairy Science, 97(12), 7985- 
516 Mayes, R. W., Lamb, C. S., \& Colgrove, P. M. (1986). The use of dosed and herbage n-alkanes as markers for the determination of herbage intake. The Journal of Agricultural Science, 107(1), 161-170. https://doi.org/10.1017/S0021859600066910

Morales-Almaráz, E., Soldado, A., González, A., Martínez-Fernández, A., Domínguez-Vara, I., de la

0
Roza-Delgado, B., \& Vicente, F. (2010). Improving the fatty acid profile of dairy cow milk by combining grazing with feeding of total mixed ration. Journal of Dairy Research, 77(02), 225. https://doi.org/10.1017/S002202991000004X

Motupalli, P. R., Sinclair, L. A., Charlton, G. L., Bleach, E. C., \& Rutter, S. M. (2014). Preference and behavior of lactating dairy cows given free access to pasture at two herbage masses and two distances. Journal of Animal Science, 92, 5175-5184. https://doi.org/10.2527/jas.20148046

Mufungwe, J., Rutter, S. M., Birch, S., Huntington, J. A., Wilkinson, R. G., \& Sinclair, L. A. (2014). The influence of time of access to pasture and provision of a total mixed ration on the intake, milk fatty acid profile and methane production of high yielding dairy cows. Advances in Animal Biosciences, 5, 96. https://doi.org/10.1017/S2040470014000028

Pérez-Prieto, L. A., \& Delagarde, R. (2013). Meta-analysis of the effect of pasture allowance on pasture intake, milk production, and grazing behavior of dairy cows grazing temperate grasslands. Journal of Dairy Science, 96(10), 6671-6689. https://doi.org/10.3168/jds.20136964

Rind, M.I., \& Phillips, C.J.C. (1999). The effects of group size on the ingestive and social behaviour of grazing dairy cows. Animal Science, 68(4), 589-596. doi:10.1017/S135772980005061X.

Sinclair, L. A., Cooper, S. L., Chikunya, S., Wilkinson, R. G., Hallett, K. G., Enser, M., \& Wood, J. D. (2005). Biohydrogenation of n-3 polyunsaturated fatty acids in the rumen and their effects on microbial metabolism and plasma fatty acid concentrations in sheep. Animal Science, 81(2), 239-248. https://doi.org/10.1079/asc50040239 
541 Sinclair, K. D., Garnsworthy, P. C., Mann, G. E. and L.A. Sinclair. 2014. Reducing dietary protein in dairy cow diets: implications for nitrogen utilization, milk production, welfare and fertility. Animal, 8, 262-274. http://doi.org/10.1017/S1751731113002139.

544 Smit, H. J., Taweel, H. Z., Tas, B. M., Tamminga, S., \& Elgersma, A. (2005). Comparison of

Sjaunja, L.O., Baevre, L., Junkkarinen, L. Pedersen, J., Setälä, J. (1990). A Nordic proposal for an energy corrected milk (ECM) formula. In: Twenty seventh Session of the International

Soriano, F. D. D., Polan, C. E. E., \& Miller, C. N. N. (2001). Supplementing pasture to lactating Holsteins fed a total mixed ration diet. Journal of Dairy Science, 84(11), 2460-2468. https://doi.org/10.3168/jds.S0022-0302(01)74696-6

Sutton, J. D. (1986). Milk composition. In W. H. Broster, R. H. Phipps, \& C. L. Johnson (Eds.), Principles and Practice of Feeding Dairy Cows (Technical, pp. 203-218). Reading, UK.: National Institute for Research in Dairying.

Tayyab, U., Wilkinson, R. G., Charlton, G. L., Reynolds, C. K., \& Sinclair, L. A. (2019). Grass silage particle size when fed with or without maize silage alters performance, reticular $\mathrm{pH}$ and metabolism of Holstein-Friesian dairy cows. Animal, 13(3), 524-532. https://doi.org/10.1017/S1751731118001568

Tayyab, Usama, Wilkinson, R. G., Reynolds, C. K., \& Sinclair, L. A. (2018). Particle size distribution of forages and mixed rations, and their relationship with ration variability and performance of UK dairy herds. Livestock Science, 217(September), 108-115. https://doi.org/10.1016/j.livsci.2018.09.018

Thomas, C. (2004). Feed into Milk: An Advisory Manual (1st ed.). Nottingham, UK: Nottingham University Press. Retrieved from http://www.bsas.org.uk/wp-content/uploads/2012/09/FiMBook.pdf 
567 Thomas, T. A. (1977). An automated procedure for the determination of soluble carbohydrates in 568 herbage. Journal of Agricultural Science, 28, 639-642.

$569 \quad$ https://doi.org/10.1002/jsfa.2740280711

570 Tozer, P. R., Bargo, F., \& Muller, L. D. (2003). Economic Analyses of Feeding Systems Combining 571 Pasture and Total Mixed Ration. Journal of Dairy Science, 86(3), 808-818.

$572 \quad$ https://doi.org/10.3168/jds.S0022-0302(03)73663-7

573 Van Soest, P. J., Robertson, J. B., \& Lewis, B. A. (1991). Methods for dietary fiber, neutral 574 detergent fiber, and nonstarch polysaccharides in relation to animal nutrition. Journal of Dairy 575 Science, 74(10), 3583-3597. https://doi.org/10.3168/jds.S0022-0302(91)78551-2

576 Vibart, R. E., Fellner, V., Burns, J. C., Huntington, G. B., \& Green, J. T. (2008). Performance of 577 lactating dairy cows fed varying levels of total mixed ration and pasture. Journal of Dairy $578 \quad$ Research, 75(04), 471. https://doi.org/10.1017/S0022029908003361

579 Wilkinson, J. M., Allen, J. D., Tunnicliffe, R., Smith, M., \& Garnsworthy, P. C. (2014). Variation in 580 composition of pre-grazed pasture herbage in the United Kingdom, 2006-2012. Animal Feed 581 Science and Technology, 196, 139-144. https://doi.org/10.1016/J.ANIFEEDSCI.2014.07.001 582 Wolf, P., Prochnow, A., \& Berg, W. (2015). Changes in land use resulting from diet modifications 583 related to increasing milk yields. Grassland Science in Europe, 20, 493-496. 
TABLE 1 Ingredient ( $\mathrm{kg} / \mathrm{kg} \mathrm{DM})$ and chemical composition of a TMR and pasture offered to dairy cows that were continuously housed or receiving TMR and grazed pasture

\begin{tabular}{|c|c|c|}
\hline & TMR & Pasture \\
\hline \multicolumn{3}{|l|}{ Ingredient } \\
\hline Maize silage & 0.416 & \\
\hline Lucerne silage & 0.117 & \\
\hline Sweetstarch $^{\mathrm{a}}$ & 0.129 & \\
\hline Rapeseed meal & 0.074 & \\
\hline Wheat distillers dark grains & 0.074 & \\
\hline Pot ale syrup ${ }^{b}$ & 0.061 & \\
\hline Soya hulls & 0.035 & \\
\hline Hipro soyabean meal & 0.031 & \\
\hline Palm kernel meal & 0.021 & \\
\hline Rumen protected fat ${ }^{\mathrm{c}}$ & 0.018 & \\
\hline Molasses & 0.006 & \\
\hline Minerals $^{\mathrm{d}}$ & 0.006 & \\
\hline Limestone flour & 0.005 & \\
\hline Feed grade urea & 0.003 & \\
\hline Buffer ${ }^{\mathrm{e}}$ & 0.002 & \\
\hline Yeast $^{\mathrm{f}}$ & 0.002 & \\
\hline \multicolumn{3}{|l|}{ Chemical composition } \\
\hline $\mathrm{DM}(\mathrm{g} / \mathrm{kg})$ & 482 & 206 \\
\hline $\mathrm{ME}(\mathrm{MJ} / \mathrm{kg} \mathrm{DM})$ & 12.2 & 12.3 \\
\hline $\mathrm{OM}$ (g/kg DM) & 930 & 895 \\
\hline Ash (g/kg of DM) & 70 & 105 \\
\hline $\mathrm{CP}(\mathrm{g} / \mathrm{kg}$ of $\mathrm{DM})$ & 176 & 175 \\
\hline WSC (g/kg DM) & 81 & 202 \\
\hline NDF (g/kg of DM) & 329 & 390 \\
\hline $\mathrm{ADF}(\mathrm{g} / \mathrm{kg}$ of $\mathrm{DM})$ & 196 & 210 \\
\hline Hemicellulose (g/kg DM) & 133 & 180 \\
\hline Fatty acids (g/kg DM) & 52.6 & 44.6 \\
\hline \multicolumn{3}{|l|}{ Fatty acids (g/100 g FA) } \\
\hline $\mathrm{C} 16: 0$ & 29.9 & 11.7 \\
\hline $\mathrm{C} 18: 0$ & 4.2 & 0.3 \\
\hline C18:1 c9 & 28.9 & 1.5 \\
\hline C18:2 c9 c12 (n-6) & 26.7 & 10.3 \\
\hline C18:3 c9 c12 c15 (n-3) & 2.8 & 41.0 \\
\hline
\end{tabular}

${ }^{a} \mathrm{KW}$ Alternative Feeds, Andover, UK; g/kg 360 cake products, 140 breakfast cereals, 140 cocoa hulls, 140 wheat feed, 70 sugar confectionery, 140 flour.

${ }^{\mathrm{b}}$ Spey syrup, KW Alternative Feeds, Andover, UK.

${ }^{c}$ Megalac, Volac International Limited, Royston, UK.

${ }^{\mathrm{d}}$ Contained the following macro minerals $(\mathrm{g} / \mathrm{kg}) 210 \mathrm{Ca}, 100 \mathrm{Mg}, 50 \mathrm{Na}, 30 \mathrm{P}$ and trace minerals $(\mathrm{mg} / \mathrm{kg}) 6000 \mathrm{Zn}, 5000 \mathrm{Mn}, 2500 \mathrm{Cu}, 400 \mathrm{I}, 70 \mathrm{Co}, 40 \mathrm{Se}$.

${ }^{\mathrm{e} A c i d}$ Buff, AB Vista, Wiltshire, UK.

fVistacell Ultra, AB Vista, Co. Antrim, Ireland. 
TABLE 2 Performance of dairy cows that were continuously housed or received $6 \mathrm{hr}$ of access to pasture.

\begin{tabular}{|c|c|c|c|c|c|c|}
\hline & $\mathrm{C}^{1}$ & EG & DG & RT & SED & $p$-value \\
\hline TMR intake (kg DM/d) & $26.9^{c}$ & $23.6^{\mathrm{b}}$ & $24.7^{\mathrm{b}}$ & $20.3^{\mathrm{a}}$ & 0.698 & $<0.001$ \\
\hline Pasture intake (kg DM/d) & --- & $2.35^{\mathrm{a}}$ & $1.98^{\mathrm{a}}$ & $3.48^{\mathrm{b}}$ & 0.449 & 0.006 \\
\hline Total intake (kg DM/d) & $26.9^{\mathrm{b}}$ & $26.0^{\mathrm{b}}$ & $26.7^{\mathrm{b}}$ & $23.8^{\mathrm{a}}$ & 0.524 & $<0.001$ \\
\hline Milk yield (kg/d) & $45.7^{\mathrm{b}}$ & $44.2^{\mathrm{ab}}$ & $44.9^{\mathrm{b}}$ & $41.7^{\mathrm{a}}$ & 0.993 & $<0.001$ \\
\hline $\operatorname{ECM}^{2}(\mathrm{~kg} / \mathrm{d})$ & 38.2 & 37.8 & 37.8 & 36.5 & 1.32 & 0.588 \\
\hline Milk fat (g/kg) & 30.6 & 32.7 & 31.3 & 33.7 & 0.18 & 0.293 \\
\hline Milk protein (g/kg) & 29.7 & 29.1 & 28.9 & 29.4 & 0.56 & 0.492 \\
\hline Milk lactose (g/kg) & 44.2 & 43.8 & 44.5 & 44.2 & 0.57 & 0.686 \\
\hline Milk fat $(\mathrm{kg} / \mathrm{d})$ & 1.44 & 1.44 & 1.36 & 1.39 & 0.088 & 0.769 \\
\hline Milk protein (kg/d) & $1.36^{\mathrm{b}}$ & $1.29^{\mathrm{ab}}$ & $1.29^{\mathrm{ab}}$ & $1.23^{\mathrm{a}}$ & 0.032 & 0.002 \\
\hline Milk lactose $(\mathrm{kg} / \mathrm{d})$ & $2.01^{\mathrm{b}}$ & $1.93^{\mathrm{ab}}$ & $2.00^{\mathrm{b}}$ & $1.84^{\mathrm{a}}$ & 0.051 & 0.005 \\
\hline Live weight (kg) & $668^{b}$ & $653^{\mathrm{a}}$ & $656^{\mathrm{ab}}$ & $647^{\mathrm{a}}$ & 4.9 & $<0.001$ \\
\hline Live weight change $(\mathrm{kg} / \mathrm{d})$ & $0.86^{\mathrm{b}}$ & $0.31^{\mathrm{a}}$ & $0.41^{\mathrm{ab}}$ & $0.09^{\mathrm{a}}$ & 0.177 & $<0.001$ \\
\hline Body condition & 2.87 & 2.83 & 2.76 & 2.76 & 0.058 & 0.186 \\
\hline $\begin{array}{l}\text { Body condition change, units } \\
28 \mathrm{~d}\end{array}$ & 0.086 & 0.047 & -0.021 & -0.021 & 0.0549 & 0.185 \\
\hline \multicolumn{7}{|c|}{$\begin{array}{l}{ }^{1} \mathrm{C}=\text { cows that were continuously housed and offered a TMR ad libitum; } \mathrm{EG}=\text { cows that were grazed } \\
\text { for } 6 \mathrm{hr} \text { directly post am milking and then housed and offered a TMR ad libitum; DG }=\text { cows that were } \\
\text { returned to housing for } 1 \mathrm{hr} \text { post am milking before being grazed for } 6 \mathrm{hr} \text { and then housed and offered a } \\
\text { TMR ad libitum; RT = cows that were grazed for } 6 \mathrm{hr} \text { directly after morning milking then housed and } \\
\text { offered a TMR restricted to } 75 \% \text { of ad libitum intake. }\end{array}$} \\
\hline
\end{tabular}


TABLE 3. Milk fatty acid composition of dairy cows that were continuously housed or received $6 \mathrm{hr}$ of access to pasture.

\begin{tabular}{|c|c|c|c|c|c|c|}
\hline & $\mathrm{C}^{1}$ & EG & DG & $\mathrm{RT}$ & SED & $p$-value \\
\hline \multicolumn{7}{|l|}{ Fatty acid $(\mathrm{g} / 100 \mathrm{~g})$} \\
\hline $\mathrm{C} 4: 0$ & 5.45 & 5.34 & 5.31 & 5.27 & 0.202 & 0.830 \\
\hline C6:0 & 2.62 & 2.69 & 2.41 & 2.44 & 0.131 & 0.115 \\
\hline $\mathrm{C} 8: 0$ & $1.33^{\mathrm{b}}$ & $1.41^{\mathrm{ab}}$ & $1.20^{\mathrm{a}}$ & $1.22^{\mathrm{ab}}$ & 0.079 & 0.040 \\
\hline $\mathrm{C} 10: 0$ & $2.69^{\mathrm{ab}}$ & $2.91^{\mathrm{b}}$ & $2.43^{\mathrm{a}}$ & $2.42^{\mathrm{a}}$ & 0.177 & 0.025 \\
\hline $\mathrm{C} 12: 0$ & $3.11^{\mathrm{bc}}$ & $3.25^{\mathrm{c}}$ & $2.80^{\mathrm{ab}}$ & $2.68^{\mathrm{a}}$ & 0.173 & 0.006 \\
\hline $\mathrm{C} 14: 0$ & $9.63^{\mathrm{ab}}$ & $9.88^{b}$ & $9.33^{\mathrm{ab}}$ & $8.80^{\mathrm{a}}$ & 0.341 & 0.018 \\
\hline C14:1 c9 & 1.06 & 0.88 & 0.94 & 0.91 & 0.097 & 0.321 \\
\hline $\mathrm{C} 15: 0$ & $0.89^{\mathrm{b}}$ & $0.84^{\mathrm{ab}}$ & $0.91^{\mathrm{b}}$ & $0.75^{\mathrm{a}}$ & 0.051 & 0.015 \\
\hline $\mathrm{C} 16: 0$ & $28.2^{\mathrm{b}}$ & $27.6^{\mathrm{ab}}$ & $26.1^{\mathrm{a}}$ & $26.8^{\mathrm{ab}}$ & 0.56 & 0.004 \\
\hline $\mathrm{C} 16: 1 \mathrm{c} 7$ & 1.66 & 1.48 & 1.66 & 1.82 & 0.163 & 0.253 \\
\hline $\mathrm{C} 17: 0$ & $0.46^{\mathrm{a}}$ & $0.48^{\mathrm{ab}}$ & $0.52^{\mathrm{b}}$ & $0.50^{\mathrm{ab}}$ & 0.019 & 0.009 \\
\hline C18:0 & 7.16 & 7.55 & 7.40 & 7.41 & 0.446 & 0.851 \\
\hline $\mathrm{C} 18: 1 \mathrm{t} 9$ & 0.53 & 0.51 & 0.55 & 0.57 & 0.040 & 0.562 \\
\hline $\mathrm{C} 18: 1 \mathrm{t} 11$ & 0.65 & 0.68 & 0.64 & 0.74 & 0.086 & 0.638 \\
\hline $\mathrm{C} 18: 1 \mathrm{t} 12$ & $0.96^{\mathrm{a}}$ & $1.24^{\mathrm{b}}$ & $1.22^{\mathrm{b}}$ & $1.24^{\mathrm{b}}$ & 0.086 & 0.004 \\
\hline C18:1cis 9 & $21.5^{\mathrm{ab}}$ & $21.1^{\mathrm{a}}$ & $23.1^{\mathrm{ab}}$ & $23.3^{b}$ & 0.93 & 0.044 \\
\hline C18:1 c9, c12 (n-6) & 2.61 & 2.45 & 2.53 & 2.58 & 0.107 & 0.457 \\
\hline C18:2 c9 t11 & 0.69 & 0.78 & 0.78 & 0.82 & 0.052 & 0.123 \\
\hline $\mathrm{C} 18: 2 \mathrm{t} 10 \mathrm{c} 12$ & 0.12 & 0.07 & 0.07 & 0.05 & 0.027 & 0.084 \\
\hline C18:3 c9 c12 c15 (n-3) & $0.31^{\mathrm{a}}$ & $0.40^{\mathrm{b}}$ & $0.40^{\mathrm{b}}$ & $0.41^{\mathrm{b}}$ & 0.022 & $<0.001$ \\
\hline $\mathrm{C} 22: 0$ & 0.09 & 0.05 & 0.04 & 0.06 & 0.019 & 0.057 \\
\hline C20:5 c7 c8 c11 c14 c17 (n-3) & 0.02 & 0.03 & 0.03 & 0.02 & 0.008 & 0.506 \\
\hline Other & 7.04 & 7.07 & 8.24 & 7.57 & 0.687 & 0.274 \\
\hline \multicolumn{7}{|l|}{ Summation by degree of saturation } \\
\hline SAT & $61.6^{\mathrm{ab}}$ & $62.0^{\mathrm{b}}$ & $58.5^{\mathrm{a}}$ & $58.4^{\mathrm{a}}$ & 1.29 & 0.008 \\
\hline MUFA & $26.9^{\mathrm{ab}}$ & $26.5^{\mathrm{a}}$ & $28.6^{\mathrm{ab}}$ & $29.3^{b}$ & 0.99 & 0.016 \\
\hline PUFA & 4.53 & 4.51 & 4.68 & 4.74 & 0.161 & 0.397 \\
\hline \multicolumn{7}{|l|}{ Summation by length } \\
\hline$<\mathrm{C} 16$ & $26.8^{\mathrm{ab}}$ & $27.2^{\mathrm{b}}$ & $25.3^{\mathrm{ab}}$ & $24.5^{\mathrm{a}}$ & 0.09 & 0.020 \\
\hline $\mathrm{C} 16: 0$ and $\mathrm{C} 16: 1$ & $30.2^{\mathrm{b}}$ & $29.5^{\mathrm{ab}}$ & $28.2^{\mathrm{a}}$ & $29.1^{\mathrm{ab}}$ & 0.58 & 0.012 \\
\hline$>\mathrm{C} 16$ & $36.0^{\mathrm{a}}$ & $36.2^{\mathrm{ab}}$ & $38.2^{\mathrm{ab}}$ & $38.8^{\mathrm{b}}$ & 1.12 & 0.032 \\
\hline
\end{tabular}

${ }^{1} \mathrm{C}=$ cows that were continuously housed and offered a TMR ad libitum; $\mathrm{EG}=$ cows that were grazed for $6 \mathrm{hr}$ directly post am milking and then housed and offered a TMR ad libitum; DG = cows that were returned to housing for $1 \mathrm{hr}$ post am milking before being grazed for $6 \mathrm{hr}$ and then housed and offered a TMR ad libitum; RT = cows that were grazed for $6 \mathrm{hr}$ directly after morning milking then housed and offered a TMR restricted to $75 \%$ of ad libitum intake. 
TABLE 4 Behaviour of dairy cows that were continuously housed or received $6 \mathrm{hr}$ of access to pasture.

\begin{tabular}{|c|c|c|c|c|c|}
\hline & $\mathrm{C}^{1}$ & EG & DG & RT & $p$-value \\
\hline \multicolumn{6}{|c|}{ Behaviour at pasture, $\%$ of time visually observed } \\
\hline Grazing & --- & $40.9 \pm 4.3$ & $40.2 \pm 3.4$ & $47.7 \pm 3.2$ & 0.292 \\
\hline Ruminating & --- & $33.7 \pm 2.3$ & $32.7 \pm 1.8$ & $31.7 \pm 2.3$ & 0.792 \\
\hline Drinking & --- & $1.5 \pm 0.2$ & $1.7 \pm 0.2$ & $1.1 \pm 0.2$ & 0.108 \\
\hline Idling & --- & $23.8 \pm 3.4$ & $25.4 \pm 2.7$ & $19.6 \pm 2.2$ & 0.318 \\
\hline Lying & --- & $41.5 \pm 3.5$ & $45.8 \pm 3.8$ & $39.2 \pm 4.0$ & 0.462 \\
\hline Standing & --- & $55.2 \pm 3.5$ & $52.5 \pm 3.6$ & $59.3 \pm 3.9$ & 0.433 \\
\hline Walking & --- & $3.4 \pm 0.4$ & $1.7 \pm 0.3$ & $1.5 \pm 0.4$ & 0.003 \\
\hline \multicolumn{6}{|c|}{ Behavioural measurements (grazing and housed) measured automatically } \\
\hline Lying time $(\min / \mathrm{d})$ & $630 \pm 13.0^{\mathrm{b}}$ & $563 \pm 15.4^{\mathrm{a}}$ & $574 \pm 11.7^{\mathrm{a}}$ & $560 \pm 10.7^{\mathrm{a}}$ & $<0.001$ \\
\hline Lying bouts (per d) & $\begin{array}{l}12.8 \pm \\
0.35^{\mathrm{b}}\end{array}$ & $9.6 \pm 0.31^{\mathrm{a}}$ & $9.6 \pm 0.30^{\mathrm{a}}$ & $9.9 \pm 0.32^{\mathrm{a}}$ & $<0.001$ \\
\hline $\begin{array}{l}\text { Lying bout duration } \\
\text { (min/bout) }\end{array}$ & $\begin{array}{l}53.5 \pm \\
1.23^{\mathrm{b}}\end{array}$ & $61.4 \pm 1.66^{\mathrm{a}}$ & $64.9 \pm 2.19^{\mathrm{a}}$ & $60.1 \pm 1.54^{\mathrm{a}}$ & $<0.001$ \\
\hline Steps (per d) & $\begin{array}{l}1137 \pm \\
65.3^{\mathrm{b}}\end{array}$ & $1592 \pm 48.8^{\mathrm{a}}$ & $1592 \pm 34.6^{\mathrm{a}}$ & $1563 \pm 28.7^{\mathrm{a}}$ & $<0.001$ \\
\hline
\end{tabular}

${ }^{1} \mathrm{C}=$ cows that were continuously housed and offered a TMR ad libitum; $\mathrm{EG}=$ cows that were grazed for $6 \mathrm{hr}$ directly post am milking and then housed and offered a TMR ad libitum; DG $=$ cows that were returned to housing for $1 \mathrm{hr}$ post am milking before being grazed for $6 \mathrm{hr}$ and then housed and offered a TMR ad libitum; $\mathrm{RT}=$ cows that were grazed for $6 \mathrm{hr}$ directly after morning milking then housed and offered a TMR restricted to $75 \%$ of ad libitum intake.

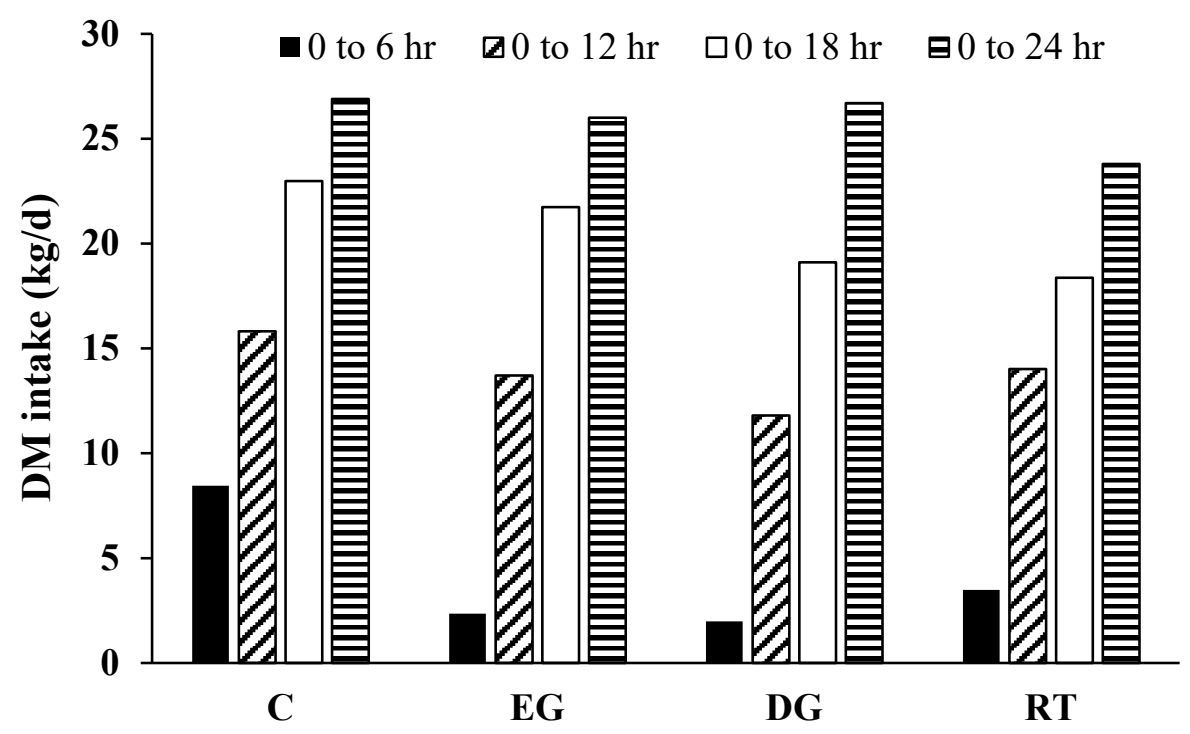


FIGURE 1 Cumulative DM intake in cows that were continuously housed and offered a TMR ad libitum (C); grazed for $6 \mathrm{hr}$ directly post am milking and then housed and offered a TMR ad libitum (EG); returned to housing for $1 \mathrm{hr}$ post am milking before being grazed for $6 \mathrm{hr}$ and then housed and offered a TMR ad libitum (DG); grazed for $6 \mathrm{hr}$ directly after morning milking then housed and offered a TMR restricted to $75 \%$ of ad libitum intake (RT). Hours 0 to 6 relate to the grazing period. For cows that were continuously housed the $6 \mathrm{hr}$ blocks relate to the same period as EG and RT.

Treatment $p<0.001$; SED 0.86, Time $p<0.001$; SED 0.39, Treatment $\mathrm{x}$ Time $p<0.001$; SED 1.09. 